\title{
Folate Receptor Alpha Positive
}

National Cancer Institute

\section{Source}

National Cancer Institute. Folate Receptor Alpha Positive. NCI Thesaurus. Code C131327.

An indication that folate receptor alpha has been detected in a sample. 